Supplement of Biogeosciences, 15, 4973-4993, 2018

https://doi.org/10.5194/bg-15-4973-2018-supplement

(C) Author(s) 2018. This work is distributed under

the Creative Commons Attribution 4.0 License.

(c) (1)

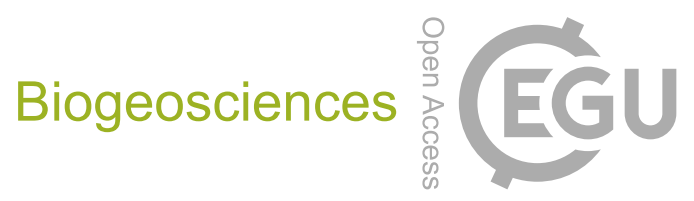

Supplement of

\title{
Mechanisms of dissolved and labile particulate iron supply to shelf waters and phytoplankton blooms off South Georgia, Southern Ocean
}

Christian Schlosser et al.

Correspondence to: Christian Schlosser (cschlosser@geomar.de)

The copyright of individual parts of the supplement might differ from the CC BY 4.0 License. 


\section{Supplementary Text}

\section{Text S1: Seawater sampling and analysis}

3

4

Water column samples were collected using trace metal clean OTE bottles deployed on a Kevlar line. The OTE bottles were transferred into the clean container where all sample handling was performed. Dissolved and total dissolvable seawater samples were acidified immediately with concentrated trace metal grade nitric acid $\left(\mathrm{HNO}_{3}, \mathrm{UpA}\right.$, Romil) to $\mathrm{pH} 1.66$ (22 mmol $\left.\mathrm{H}^{+} \mathrm{L}^{-1}\right)$. Acidified seawater samples were shipped to the National Oceanography Centre Southampton and analyzed by isotope dilution (ID) and standard addition inductively coupled plasma - mass spectrometry (ICP-MS).

The preconcentration and ICP-MS analysis was adapted from the method outlined by Rapp et al. (2017). Approximately one year after collection, $12 \mathrm{~mL}$ of acidified seawater was transferred into $30 \mathrm{~mL}$ fluorinated ethylene propylene (FEP) bottles and spiked with a spike solution containing mainly the artificially enriched isotope of iron $\left({ }^{57} \mathrm{Fe}\right)$. For the analysis of $\mathrm{Al}$, and $\mathrm{Mn}$ a series of four standard additions were performed on every tenth sample. To obtain equimolar conditions between the spike and the natural seawater concentration, larger amounts of spike was added to the total dissolvable seawater samples. All samples were irradiated with strong ultraviolet light for 3.5 hours. Subsequently, the sample solution was buffered to $\mathrm{pH} 6.4$ using a $2 \mathrm{M}$ ammonium acetate solution (pH9.2, Fisher Optima grade ammonia and acetic acid, glacial). Immediately after buffer addition the solution was preconcentrated using an automated system (Preplab, PS Analytical) that was equipped with a metal chelating resin (WACO) resin (Kagaya et al., 2009). Any remaining seawater salts were rinsed off using deionized water ( $>18 \mathrm{M} \Omega \mathrm{cm}$, MilliQ, Millipore). The metals retained on the resin were eluted using $1 \mathrm{~mL}$ of a $1 \mathrm{M}$ sub-boiled $\mathrm{HNO}_{3}$ solution, which was collected in acid cleaned $4 \mathrm{~mL}$ polypropylene vials. The collected vials were placed into the autosampler of the ICP-MS (Element XR, Thermo). 
concentrations was used to determine the particulate concentration $\left(\mathrm{LP}_{\mathrm{UN}} \mathrm{M}=\mathrm{TDM}-\mathrm{DM}\right)$. It $22 \mathrm{mmol} \mathrm{H} \mathrm{L}^{-1}$. This means acid-inert minerals (e.g. zircon) and their associated trace metals likely did not contribute to the particulate metal concentration. and analyzed with each batch of samples, in order to validate our sample concentration.

Values obtained by us for the certified seawater standards agreed with reported values for the GEOTRACES and the SAFe standard seawater (SAFe D2: $0.92 \pm 0.02 \mathrm{nmol} \mathrm{Fe} \mathrm{L}^{-1}$ (certified $\left.0.90 \pm 0.02 \mathrm{nmol} \mathrm{Fe} \mathrm{L}{ }^{-1}\right)$, GEOTRACES D: $1.00 \pm 0.04 \mathrm{nmol} \mathrm{Fe} \mathrm{L}{ }^{-1}$ (certified $0.95 \pm 0.05$ nmol Fe $\mathrm{L}^{-1}$ ). The precision for replicate analyses was between 1-3\%. The buffer blank was $0.056 \pm 0.016\left(\sigma_{\mathrm{bl}}\right) \mathrm{nmol} \mathrm{Fe} \mathrm{L}^{-1}$, and the limit of detection $(3 \mathrm{x}$ standard deviation of the

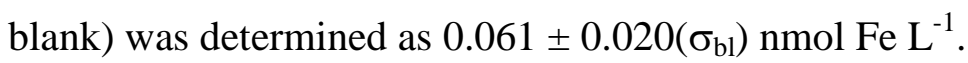
analysed with each batch of suspended particle and faecal pellet samples, in order to validate our sample concentration. Values obtained agreed with reported values of the crm (NIST 1573a: $423 \pm 5 \mathrm{mg} \mathrm{Fe} \mathrm{kg}^{-1}$ (certified $368 \pm 7 \mathrm{mg} \mathrm{Fe} \mathrm{kg}^{-1}$ ), $244 \pm 2 \mathrm{mg} \mathrm{Mn} \mathrm{kg}^{-1}$ (certified 246 $44 \pm 8 \mathrm{mg} \mathrm{Mn} \mathrm{kg}^{-1}$ ), $550 \pm 1 \mathrm{mg} \mathrm{Al} \mathrm{kg}^{-1}$ (certified $598 \pm 12 \mathrm{mg} \mathrm{Al} \mathrm{kg}^{-1}$ ); Tort-2: $117 \pm 2 \mathrm{mg} \mathrm{Fe}$ $45 \mathrm{~kg}^{-1}$ (certified $\left.105 \pm 13 \mathrm{mg} \mathrm{Fe} \mathrm{kg}^{-1}\right), 13 \pm 1 \mathrm{mg} \mathrm{Mn} \mathrm{kg}^{-1}\left(\right.$ certified $\left.14 \pm 1 \mathrm{mg} \mathrm{Mn} \mathrm{kg}{ }^{-1}\right)$ ). Text S2: Sediment and porewater sampling and analysis Sediment cores with an undisturbed sediment-seawater interface were immediately transferred to a $\mathrm{N}_{2}$-filled glove bag in a temperature-controlled laboratory to simulate ambient 49 bottom water temperatures (approximately $4{ }^{\circ} \mathrm{C}$ ). Sediments were manually extruded at depth intervals of 1 or $2 \mathrm{~cm}$ into a polycarbonate ring, and sectioned using a polytetrafluoroethylene 
51 (PTFE) sheet that was cleaned with deionised water between each application. Porewater was separated from each sediment section by centrifugation at $9,000 \mathrm{~g}$ at $4^{\circ} \mathrm{C}$ under $\mathrm{N}_{2}$ for 10 minutes; the supernatant porewaters were filtered under $\mathrm{N}_{2}$ through $0.2 \mu \mathrm{m}$ cellulose nitrate syringe filters (Whatman, UK). Aliquots of each porewater sample were collected in acidcleaned LDPE bottles (Nalgene) and acidified to $\mathrm{pH}<2$ by adding $2 \mu \mathrm{L}$ of concentrated hydrochloric acid (HCl, UpA, Romil) per $1 \mathrm{~mL}$ of sample; acidified samples were stored refrigerated prior to analysis at NOCS. Conjugate sediments were freeze dried on board and stored at room temperature, pending analysis at the NOCS. Sub-samples $(\sim 100 \mathrm{mg})$ of the bulk, homogenized sediments were completely

60 dissolved using hot aqua regia $\left(\mathrm{HNO}_{3}+\mathrm{HCl}\right)$ followed by hot hydrofluoric-perchloric acid $61\left(\mathrm{HF}^{-} \mathrm{HClO}_{4}\right)$ mixtures and finally diluted in $0.6 \mathrm{M} \mathrm{HCl}$ as described elsewhere (Homoky et al., 2011). The acid digests were analysed by ICP-OES (Perkin Elmer Optima 4300DV). Calibration standards were matrix-matched and blank and instrument drift were monitored and corrected for by including calibration blanks and multi-element standards with each batch of 10 analyses. To ascertain the accuracy of the method certified reference material MAG-1 (United Sates Geological Survey) was analysed with each batch of samples. The values

67 measured in our laboratory are in close agreement with the certified values: $42.978 \pm 3.155 \mathrm{~g}$ $68 \mathrm{Fe} \mathrm{kg}^{-1}$ (certified $47.600 \pm 4.200 \mathrm{~g} \mathrm{Fe} \mathrm{kg}^{-1}$ ); $715 \pm 9 \mathrm{ng} \mathrm{Mn} \mathrm{g}{ }^{-1}$ (certified $760 \pm 69 \mu \mathrm{g} \mathrm{Mn} \mathrm{kg}^{-}$ ${ }^{1}$ ); and $76.605 \pm 2.740 \mathrm{~g} \mathrm{Al} \mathrm{kg}^{-1}$ (certified $86.800 \pm 1.600 \mathrm{~g} \mathrm{Al} \mathrm{kg}^{-1}$ ).

Acidified porewater samples were analysed for a suite of major and trace elements, by 71 ICP-OES (Perkin Elmer Optima 4300 DV). Elements including Fe and Mn were measured at 7250 -fold dilutions of the porewater sample in $0.6 \mathrm{M} \mathrm{HCl}$. Calibration standards were matrix 73 matched and blank and instrument drift were monitored and corrected for by including 74 calibration blanks and multi-element standards for each batch of ten analyses. The instrument 
75 limits of detection (LD, 3 x standard deviation of acid blanks) were $1.25 \mu \mathrm{g} \mathrm{Fe} \mathrm{kg}^{-1}$ and 0.08 $76 \mu \mathrm{g} \mathrm{Mn} \mathrm{kg}{ }^{-1}$.

77 Text S3: Calculation of dissolved Fe and Mn fluxes from shelf sediment porewaters

The calculation of pore water Fe and Mn fluxes follows the approach of Boudreux and Scott (1978), who described the flux of pore water Mn(II) by diffusion and reaction through an oxygenated surface layer in marine sediments.

$$
J=\frac{\varphi\left(D_{s} k_{1}\right)^{0.5} C_{p}}{\sinh \left(\left(k_{1} / D_{s}\right)^{0.5} L\right)}
$$

Where $J$ is the flux $\left(\mathrm{g} \mathrm{cm}^{-2} \mathrm{~s}^{-1}\right)$ of $\mathrm{Mn}$ (II) from sediment pore water to bottom water,

$L$ is the thickness $(\mathrm{cm})$ of the oxygenated surface layer where $\mathrm{Mn}(\mathrm{II})$ is removed from the pore water by oxidative precipitation in the sediment, and $C_{p}$ is the concentration $\left(\mathrm{g} \mathrm{cm}^{-3}\right)$ of $\mathrm{Mn}(\mathrm{II})$ in the pore water beneath $L$ relative to the overlying bottom water. The diffusive rate constant, $D_{\mathrm{s}}\left(\mathrm{cm}^{2} \mathrm{~s}^{-1}\right)$, is derived from sediment porosity $(\varphi)$, and the $\mathrm{Mn}(\mathrm{II})$ oxidation rate constant, $k_{1}\left(\mathrm{~s}^{-1}\right)$, is estimated from field studies (Boudreux and Scott, 1978). This method has more recently been adopted for the determination of pore water Fe(II) fluxes (Homoky et al., 2013; Raiswell and Anderson, 2005) using the Fe(II) oxidation kinetics of (Millero et al., 1987) to derive $k_{1}$, and has been favourably compared with incubated flux determinations from shelf sediments (Homoky et al., 2012).

We use measured and estimated values for scalar terms for the flux calculations that are summarised in Supplementary Table S1 to investigate the potential for pore water fluxes of Fe and Mn from sites S1, S2 and S3. Sediment porosity $(\varphi)$ was measured by the change in wet sediment mass after drying sliced core samples. Oxygen penetration depth $(L)$ was measured from a single sediment core from site S3 with a Unisense microsensor apparatus following Homoky et al. (2013), and in the absence of multiple determinations is extrapolated to each core site. Diffusion coefficients $\left(D_{\mathrm{S}}\right)$ are a derived from measurements of $\varphi$ after Boudreau and Scoot (1978). The oxidation rate constant $\left(k_{1}\right)$ for $\mathrm{Mn}(\mathrm{II})$ is also derived from 
99 Boudreau and Scoot (1978). For $\mathrm{Fe}(\mathrm{II}), k_{1}$ is calculated from values of bottom water $\mathrm{O}_{2}$,

100 temperature $\left(0{ }^{\circ} \mathrm{C}\right)$, salinity (34) and an estimated pore water $\mathrm{pH}$ of 7.5 (Homoky et al.,

101 2012), following Millero et al. (1987) (Homoky et al., 2013; Homoky et al., 2012; Raiswell

102 and Anderson, 2005). Values of $C_{\mathrm{P}}$ are for measured data (at 0.5 and $1.5 \mathrm{~cm}$ depth) closest to

103 the depth of $L$ from each core site. Corresponding fluxes of pore water Fe $(<0.1$ to $44.4 \mu \mathrm{mol}$

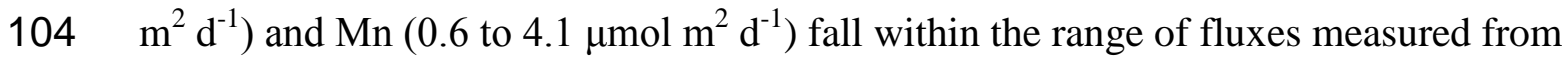

105 continental margin sediments of the northeast Pacific (John et al., 2012; McManus et al.,

106 2012) and demonstrate South Georgia shelf sediments are also likely to be an important

107 source of $\mathrm{Fe}$ and $\mathrm{Mn}$ to the water column.

108 Text S4: Estimation of phytoplankton Fe requirements and Fe fluxes

109 The Fe requirements of the phytoplankton community within the bloom were estimated by

110 combining satellite derived marine net primary productivity data $\left(\mathrm{NPP}=62 \pm 21 \mathrm{mmol} \mathrm{C} \mathrm{m}^{-2}\right.$

$111 \mathrm{~d}^{-1}$ (Ma et al., 2014)) with an average intracellular Fe:C ratio $\left(5.2 \pm 2.8 \mu \mathrm{mol} \mathrm{Fe} \mathrm{mol}{ }^{-1} \mathrm{C}^{-1}\right.$

112 (Strzepek et al., 2011)). NPP was estimated from satellite-derived information using a

113 phytoplankton pigment absorption based model (Ma et al., 2014). The applied NPP rate

114 corresponded to an average chlorophyll a content in the euphotic zone of $\sim 4 \mathrm{ug} \mathrm{L}^{-1}$. There

115 are several literature values for $\mathrm{Fe}: \mathrm{C}$ ratio estimates ranging from $6-14 \mu \mathrm{mol} \mathrm{Fe} \mathrm{mol}^{-1} \mathrm{C}^{-1}$

116 under natural non Fe-fertilized and $10-40 \mu \mathrm{mol} \mathrm{Fe} \mathrm{mol}^{-1} \mathrm{C}^{-1}$ under Fe-fertilized conditions

117 for Southern Ocean diatoms, autotrophic flagellates, and heterotrophic flagellates (Twining et

118 al., 2004). Lab based incubation experiments using coastal phytoplankton species, such as

119 Dunaliella tertiolecta, Pyramimonas parkeae, Nannochloris atomus, Pycnococcus provasoli,

120 Tetraselmis sp., Gymnodinium chlorophorum, Prorocentrum mimimum, Amphidinium

121 carterae, Thoracosphaera heimii, Emiliania huxleyia, Gephyrocapsa oceanica, Ditylum

122 brightwellii, Thalassiosira weissflogii, Nitzschia brevirostris, and Thalassiosira eccentric,

123 reviled an average value of $\sim 51 \mu \mathrm{mol} \mathrm{Fe} \mathrm{mol}^{-1} \mathrm{C}^{-1}$ (Ho et al., 2003), while Southern Ocean 
124 phytoplankton species including Phaeocystis antarctica (clone AA1), Fragilariopsis

125 kerguelensis, Thalassiosira Antarctica, Eucampia Antarctica, and Proboscia inermis were an

126 order of magnitude lower between 1.8 - 8.6 (Strzepek et al., 2011). Because most

127 phytoplankton species from the Southern Ocean are very well adapted to the very low Fe

128 water content, we decided to apply the low Fe:C ratios provided by Strzepek et al. (Strzepek

129 et al., 2011). The Fe:C ratio in the blooming region is presumingly higher, thus the rather

130 low Fe:C ratio used refelcts the minimum amount of DFe that has to be supplied.

The vertical Fe flux $\left(J_{z}\right)$ was calculated using an approach outlined in de Jong et al.

132 (2012). The vertical DFe flux is the sum of advective Ekman pumping (left term) and

133 diffusion (right term).

$$
J_{z}=w[D F e]_{B W L}+K_{z}\left(\frac{\delta[D F e]}{\delta z}\right)
$$

134 The advective Fe flux term (left) expressed by the upwelling velocity $(w)$, which was set

135 constant $\sim 1.1 * 10^{-6} \mathrm{~m} \mathrm{~s}^{-1}$ (de Jong et al., 2012), and the average dissolved Fe concentration

$136\left([\mathrm{DFe}]_{B W L}\right)$ at all stations at $\sim 200 \mathrm{~m}$ depth, contributed to $38 \%$ to the entire vertical Fe flux

137 of $0.41 \mu \mathrm{mol} \mathrm{m} \mathrm{m}^{-2}$. The remaining $62 \%$ are contribution of the diffusive mixing term (right

138 term) which was derived from the DFe gradient at all stations between the surface mixed

139 layer and $\sim 200 \mathrm{~m}$ water depth and the vertical diffusivity, set constant at $K_{z}=1 *$

$140 \quad 10^{-4} \mathrm{~m}^{-2} \mathrm{~s}^{-1}$. 


\section{Supplementary Tables}

142 Table S1: Summary of pore water Fe and Mn flux parameters

\begin{tabular}{|c|c|c|c|c|c|c|c|}
\hline Parameter & Unit & ------------ & --- Fe ----- & ----------- & ------------ & ---- Mn ---- & ----------- \\
\hline Site & & $\overline{\mathrm{S} 1}$ & S2 & S3 & $\overline{\mathrm{S}} 1$ & $\begin{array}{l}\text { S2 } \\
\text { S }\end{array}$ & S3 \\
\hline Pore w. conc. $C_{\mathrm{p}}$ & $\left(\mathrm{g} \mathrm{cm}^{-3}\right)$ & $\begin{array}{c}1.7 \mathrm{E}-07 \text { to } \\
9.6 \mathrm{E}-07\end{array}$ & $\begin{array}{c}6.2 \mathrm{E}-08 \text { to } \\
8.6 \mathrm{E}-08\end{array}$ & $\begin{array}{c}9.2 \mathrm{E}-08 \text { to } \\
1.7 \mathrm{E}-06\end{array}$ & $\begin{array}{c}4.9 \mathrm{E}-08 \text { to } \\
1.3 \mathrm{E}-07\end{array}$ & $\begin{array}{c}1.8 \mathrm{E}-08 \text { to } \\
4.0 \mathrm{E}-08\end{array}$ & $\begin{array}{c}2.2 \mathrm{E}-08 \text { to } \\
2.8 \mathrm{E}-08\end{array}$ \\
\hline $\mathrm{O}_{2}$ depth, $L$ & $(\mathrm{~cm})$ & 0.7 & 0.7 & 0.7 & 0.7 & 0.7 & 0.7 \\
\hline Porosity, $\varphi$ & & 0.76 & 0.76 & 0.84 & 0.76 & 0.76 & 0.84 \\
\hline Diff. coef., $D_{\mathrm{s}}$ & $\left(\mathrm{cm}^{2} \mathrm{~s}^{-1}\right)$ & $2.076 \mathrm{E}-06$ & $2.076 \mathrm{E}-06$ & $2.461 \mathrm{E}-06$ & $1.877 \mathrm{E}-06$ & $1.877 \mathrm{E}-06$ & $2.156 \mathrm{E}-06$ \\
\hline Bottom water $\left[\mathrm{O}_{2}\right]$ & $\left(\mathrm{g} \mathrm{cm}^{-3}\right)$ & $1.574 \mathrm{E}-05$ & $1.574 \mathrm{E}-05$ & $1.700 \mathrm{E}-05$ & $1.00 \mathrm{E}-07$ & $1.00 \mathrm{E}-07$ & $1.00 \mathrm{E}-07$ \\
\hline Pore water $\mathrm{pH}$ & & 7.5 & 7.5 & 7.5 & 7.5 & 7.5 & 7.5 \\
\hline Oxidation rate, $k_{1}$ & $\left(\mathrm{~s}^{-1}\right)$ & $1.574 \mathrm{E}-05$ & $1.574 \mathrm{E}-05$ & $1.700 \mathrm{E}-05$ & $1.00 \mathrm{E}-07$ & $1.00 \mathrm{E}-07$ & $1.00 \mathrm{E}-07$ \\
\hline \multirow[t]{2}{*}{ Flux, $J$} & $\left(\mathrm{~g} \mathrm{~cm}^{3} \mathrm{~s}^{-1}\right)$ & $\begin{array}{c}2.2 \mathrm{E}-13 \text { to } \\
1.2 \mathrm{E}-12\end{array}$ & $\begin{array}{c}4.3 \mathrm{E}-15 \text { to } \\
6.1 \mathrm{E}-15\end{array}$ & $\begin{array}{c}1.6 \mathrm{E}-13 \text { to } \\
2.9 \mathrm{E}-12\end{array}$ & $\begin{array}{c}1.0 \mathrm{E}-13 \text { to } \\
2.6 \mathrm{E}-13\end{array}$ & $\begin{array}{c}3.6 \mathrm{E}-14 \text { to } \\
8.1 \mathrm{E}-14\end{array}$ & $\begin{array}{c}5.8 \mathrm{E}-14 \text { to } \\
7.3 \mathrm{E}-14\end{array}$ \\
\hline & $\left(\mu \mathrm{mol} \mathrm{m} \mathrm{d}^{2}\right)$ & 3.4 to 19.2 & $<0.1$ & 2.5 to 44.4 & 1.6 to 4.1 & 0.6 to 1.3 & 0.9 to 1.1 \\
\hline
\end{tabular}

143

144 Table S2: Fe, Mn, and Al concentrations in pore waters and sediments

\begin{tabular}{|c|c|c|c|c|c|c|c|c|}
\hline \multirow[t]{2}{*}{ Date } & \multirow[t]{2}{*}{ Station } & \multirow{2}{*}{$\begin{array}{c}\text { Sample } \\
\text { ID } \\
\end{array}$} & \multirow{2}{*}{$\begin{array}{c}\text { Sample mid-depth } \\
(\mathrm{cm})\end{array}$} & \multicolumn{2}{|c|}{ Sediment particles } & \multicolumn{3}{|c|}{ Porewater } \\
\hline & & & & $\mathrm{Fe}(\mathrm{wt} \%)$ & $\mathrm{Mn}(\mathrm{ppm})$ & $\mathrm{Al}(\mathrm{wt} \%)$ & $\mathrm{Fe}\left(\mu \mathrm{mol} \mathrm{kg}{ }^{-1}\right)$ & $\operatorname{Mn}\left(\mu \mathrm{mol} \mathrm{kg}{ }^{-1}\right)$ \\
\hline \multirow[t]{16}{*}{ Feb. 2011} & S1 (MC33) & $\mathrm{AC} 1$ & 0.5 & 3.25 & 635 & 4.77 & 3.0 & 2.421 \\
\hline & & $\mathrm{AC} 2$ & 1.5 & 3.38 & 633 & 4.70 & 17.2 & 0.940 \\
\hline & & $\mathrm{AC} 3$ & 2.5 & 3.31 & 647 & 4.78 & 110.1 & 0.546 \\
\hline & & $\mathrm{AC} 4$ & 3.5 & 3.35 & 662 & 5.01 & 105.6 & 0.675 \\
\hline & & AC5 & 4.5 & 3.22 & 649 & 4.65 & 93.5 & 0.520 \\
\hline & & AC6 & 5.5 & 3.30 & 662 & 5.02 & 81.9 & 0.389 \\
\hline & & $\mathrm{AD} 1$ & 7 & - & - & - & 52.6 & 0.271 \\
\hline & & $\mathrm{AD} 2$ & 9 & 3.11 & 615 & 4.66 & 32.6 & 0.263 \\
\hline & & AD3 & 11 & - & - & - & 27.3 & 0.304 \\
\hline & & $\mathrm{AD} 4$ & 13 & - & - & - & 6.4 & 0.293 \\
\hline & & AD5 & 15 & 3.09 & 612 & 4.69 & 2.5 & 0.209 \\
\hline & & AD6 & 17 & - & - & - & 1.4 & 0.087 \\
\hline & & AE1 & 19 & - & - & - & 0.8 & 0.040 \\
\hline & & AE2 & 21 & - & - & - & 0.8 & 0.027 \\
\hline & & $\mathrm{AE} 3$ & 23 & - & - & - & 0.7 & 0.028 \\
\hline & & $\mathrm{AE} 4$ & 25 & 2.99 & 594 & 4.31 & 0.7 & 0.008 \\
\hline \multirow[t]{3}{*}{ Feb. 2011} & S2 (MC34) & $\mathrm{AF} 1$ & 0.5 & 3.58 & 627 & 4.77 & 1.5 & 0.585 \\
\hline & & AF2 & 1.5 & 3.35 & 644 & 4.83 & - & - \\
\hline & & AF3 & 2.5 & 3.24 & 649 & 4.74 & 1.1 & 0.399 \\
\hline
\end{tabular}




\begin{tabular}{|c|c|c|c|c|c|c|c|c|}
\hline & & AF5 & 4.5 & - & - & - & 18.5 & 0.304 \\
\hline & & AG1 & 6.5 & 3.32 & 672 & 4.94 & 11.1 & 0.264 \\
\hline & & AG3 & 8.5 & - & - & - & 4.7 & 0.253 \\
\hline & & AG5 & 10.5 & 3.24 & 647 & 4.85 & 14.5 & 0.285 \\
\hline & & AH1 & 12.5 & - & - & - & 3.9 & 0.290 \\
\hline & & $\mathrm{AH} 3$ & 14.5 & 3.02 & 595 & 4.32 & 3.8 & 0.285 \\
\hline & & AH5 & 16.5 & 3.11 & 616 & 4.65 & 2.6 & 0.336 \\
\hline \multirow[t]{18}{*}{ Feb. 2011} & S3 (MC35) & AI1 & 0.5 & 3.43 & 627 & 4.49 & 1.6 & 0.597 \\
\hline & & $\mathrm{AI} 2$ & 1.5 & 3.28 & 643 & 4.75 & 29.0 & 0.465 \\
\hline & & $\mathrm{AI} 3$ & 2.5 & 3.24 & 642 & 4.75 & 91.1 & 0.373 \\
\hline & & $\mathrm{AI} 4$ & 3.5 & 3.32 & 661 & 4.88 & 40.2 & 0.342 \\
\hline & & AI5 & 4.5 & - & - & - & 37.1 & 0.262 \\
\hline & & AI6 & 5.5 & 3.16 & 636 & 4.81 & 49.3 & 0.535 \\
\hline & & $\mathrm{AJ} 1$ & 6.5 & - & - & - & 37.4 & 0.251 \\
\hline & & $\mathrm{AJ} 2$ & 7.5 & - & - & - & 61.7 & 0.322 \\
\hline & & $\mathrm{AJ} 3$ & 8.5 & 3.27 & 640 & 4.92 & 67.9 & 0.475 \\
\hline & & $\mathrm{AJ} 4$ & 11.0 & - & - & - & 48.2 & 0.398 \\
\hline & & AJ5 & 13.0 & - & - & - & 23.6 & 0.336 \\
\hline & & AJ6 & 15.0 & - & - & - & 33.5 & 0.648 \\
\hline & & AK1 & 17.0 & 3.00 & 593 & 4.57 & 3.8 & 0.181 \\
\hline & & $\mathrm{AK} 2$ & 19.0 & 3.05 & 597 & 4.51 & 1.9 & 0.075 \\
\hline & & AK3 & 21.0 & - & - & - & 1.6 & 0.005 \\
\hline & & AK5 & 25.0 & 3.08 & 615 & 4.77 & 3.2 & 0.071 \\
\hline & & AK6 & 27.0 & - & - & - & 2.9 & 0.052 \\
\hline & & AL1 & 29.0 & 3.10 & 615 & 4.83 & 5.6 & 0.095 \\
\hline
\end{tabular}




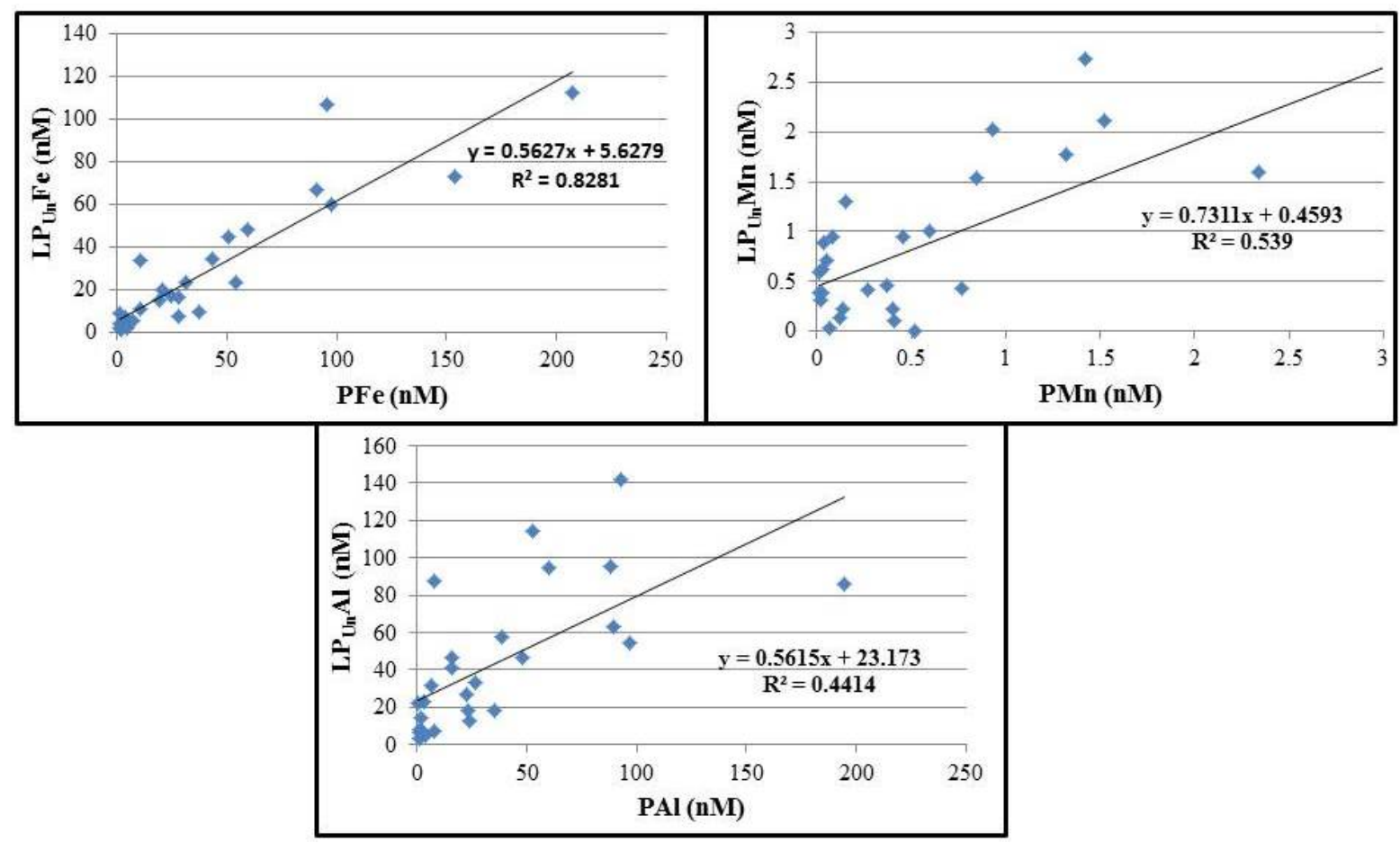

148 Figure S1: SAPS and OTE water sampler: Relationship of particulate trace metals from

149 SAPS samplers $(\mathrm{P})$ vs. leachable particulate trace metals from OTE water samplers (LP $\left.\mathrm{Un}_{\mathrm{Un}}\right)$.

150 Data represents the entire data set collected at 20m, 50, and 100/150m.

151

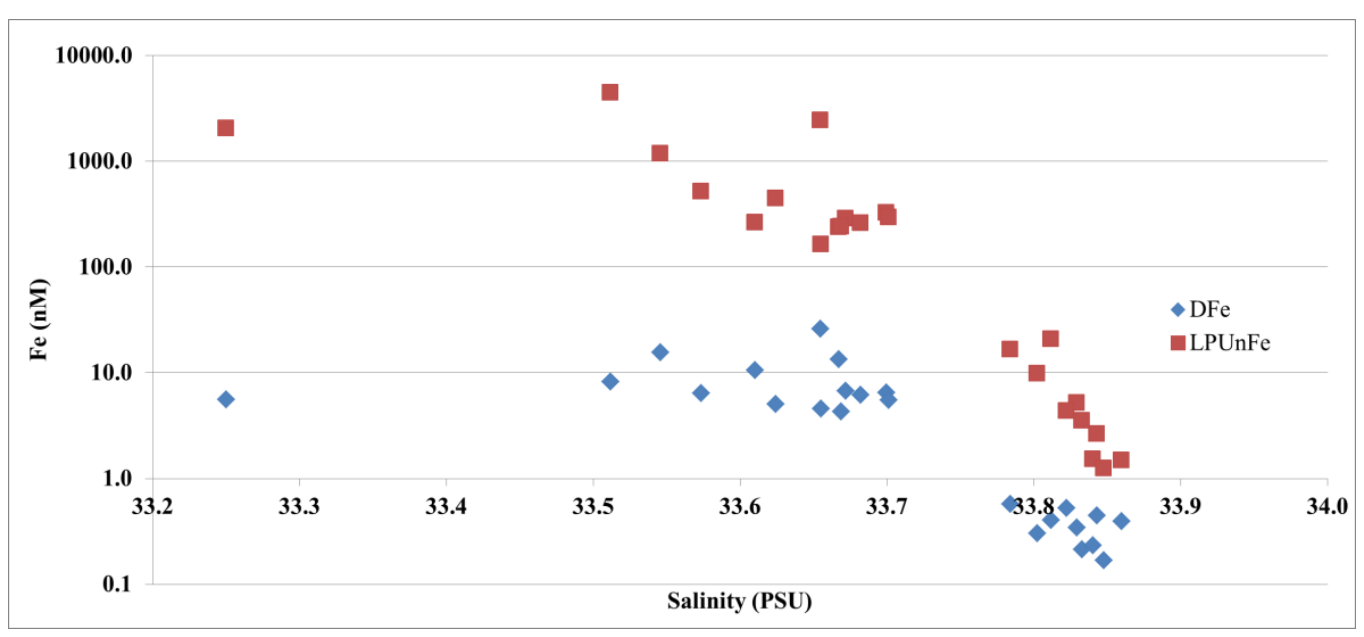

153 Figure S2: Tow-Fish surface samples: Relationship of salinity vs. dissolved (DFe) and

154 leachable particulate $\mathrm{Fe}\left(\mathrm{LP}_{\mathrm{Un}} \mathrm{Fe}\right)$ in surface waters. The Fe concentration along the y-axis is

155 represented in a logarithmic scale. We applied a linear regression, to validate the relationship 
156 between the DFe, $\mathrm{LP}_{\mathrm{Un}} \mathrm{Fe}$ and salinity (not shown). With exception of the low salinity data

157 point at $33.25 \mathrm{psu}$, the $\mathrm{DFe}$ and $\mathrm{LP}_{\mathrm{Un}} \mathrm{Fe}$ vs. salinity data achieved an $\mathrm{R}^{2}$ of 0.46 and 0.38 ,

158 respectively.

159

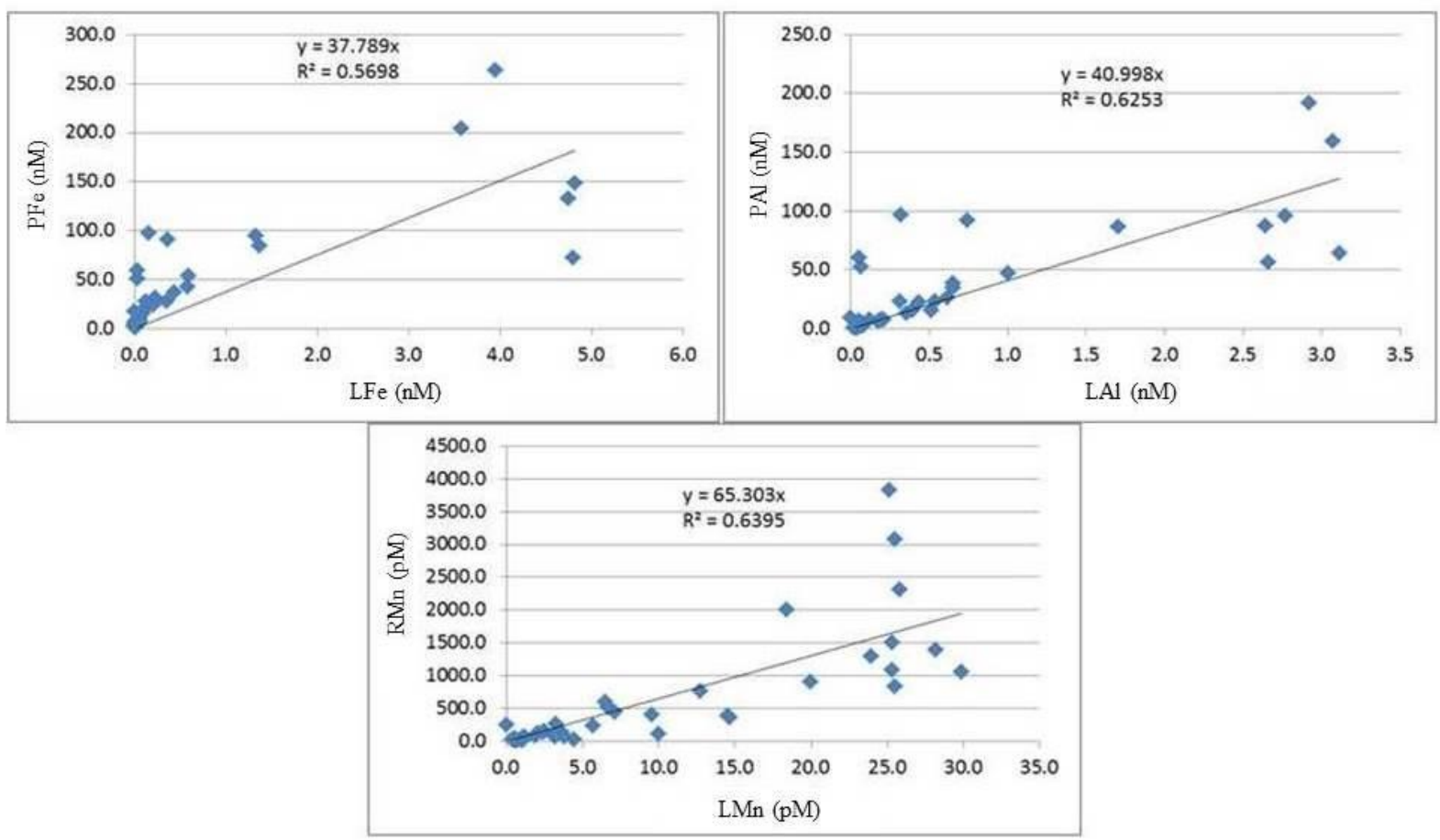

160

Figure S3: SAPS samples: Relationship between leachable (L) and refractory (R) Fe, Mn,

162 and Al. Due to the high proportion of RP $(98.9-99.2 \%$ for Fe) in the particulate fraction,

163 using the particulate fraction, $\mathrm{P}$, instead of $\mathrm{R}$ changes the linear regression with $\mathrm{L}$ just very

164 little. 

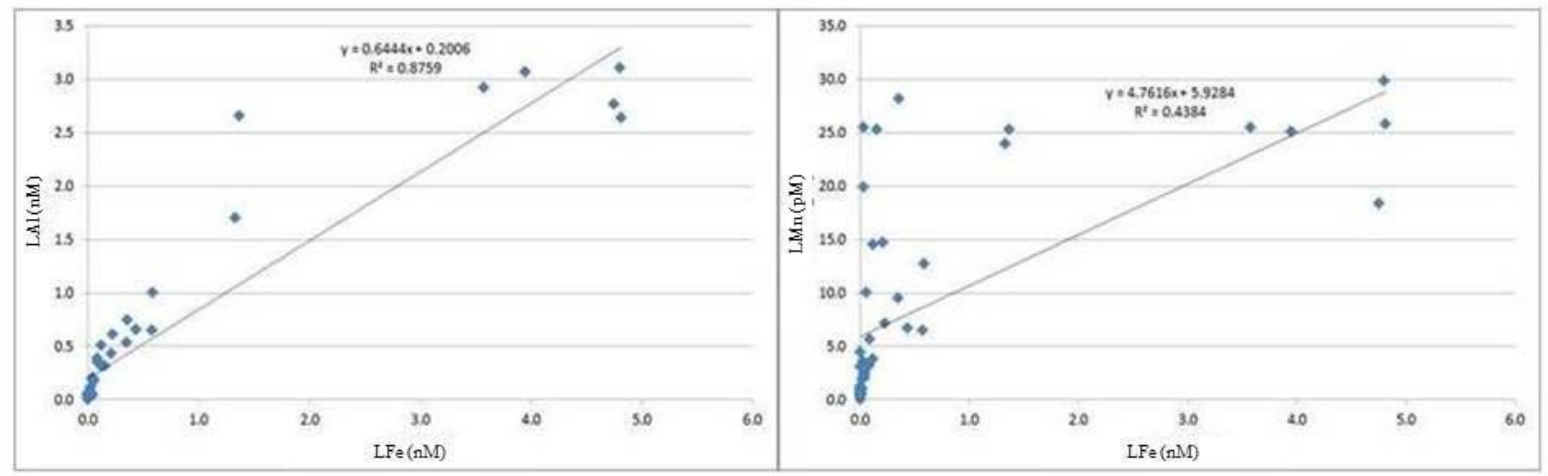

166 Figure S4: SAPS samples: Relationship between leachable Fe, Mn and Al.

167

168

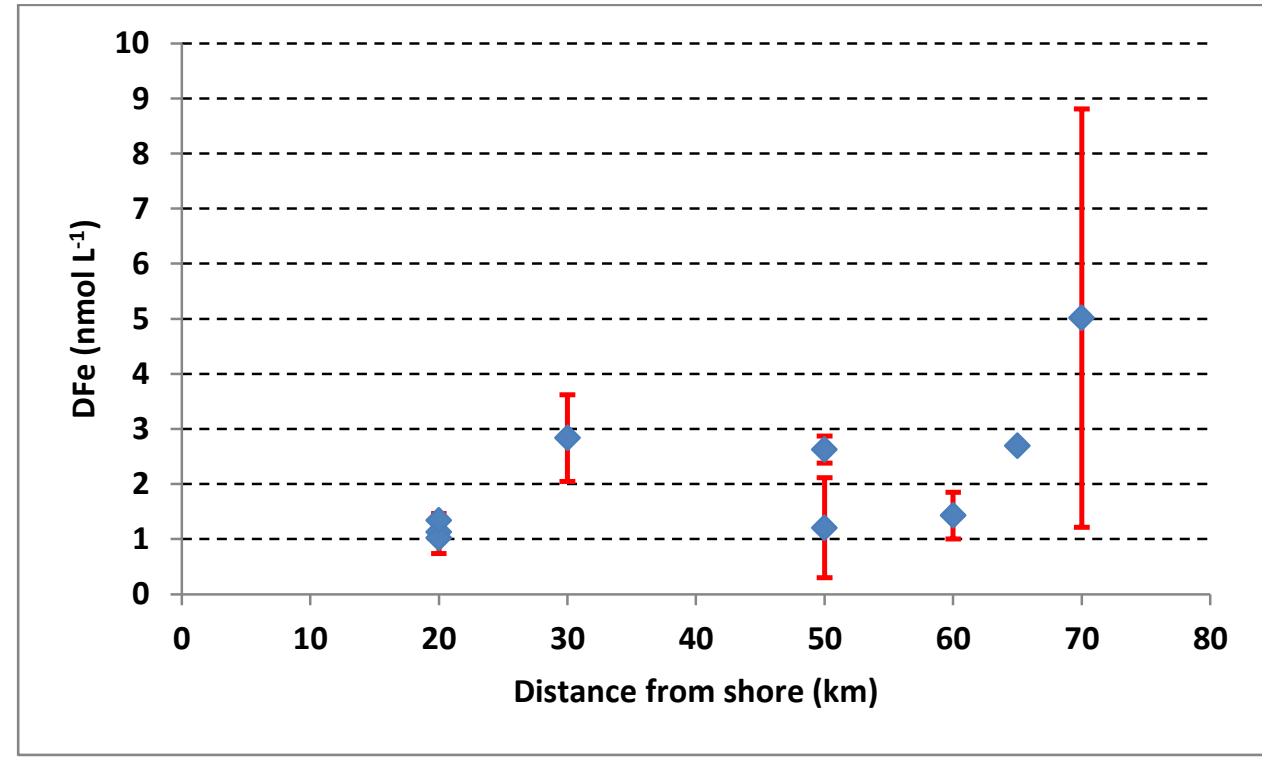

169 Figure S5: OTE-water sampler: Average dissolved Fe concentration between 100 and 400

$170 \mathrm{~m}$ water depth versus distance to the coast line of South Georgia in kilometre. 


\section{$171 \quad$ References}

172 Boudreux, B. P. and Scott, M. R.: A model for the diffusion-controlled growth of deep-sea

173 manganese nodules, Americ. J. Sc., 278, 903-929, 1978.

174 de Jong, J., Schoemann, V., Lannuzel, D., Croot, P., de Baar, H. J. W., and Tison, J. L.:

175 Natural iron fertilization of the Atlantic sector of the Southern Ocean by continental shelf

176 sources of the Antarctic Peninsula, J. Geophys. Res., 117, 1-25, 2012.

177 Ho, T.-Y., Quigg, A., Finkel, Z. V., Milligan, A. J., Wyman, K., Falkowski, P. G., and Morel,

178 F. M. M.: The elemental composition of some marine phytoplankton, J. Phycol., 39, 1145-

$1791159,2003$.

180 Homoky, W. B., John, S. G., Conway, T. M., and Mills, R. A.: Distinct iron supply and 181 isotope signatures from marine sediment dissolution, Nat. Commun., 4:2143, 2013.

182 Homoky, W. B., Severmann, S., McManus, J., Berelson, W. M., Riedel, T. E., Statham, P. J., 183 and Mills, R. A.: Dissolved oxygen and suspended particles regulate the benthic flux of iron 184 from continental margins, Mar. Chem., 134-135, 59-70, 2012.

185 John, S. G., Mendez, J., Moffett, J. W., and Adkins, J.: The flux of iron and iron isotopes 186 from San Pedro Basin sediments, Geochim. Cosmochim. Act., 93, 14-29, 2012.

187 Kagaya, S., Maebe, E., Inoue, Y., Kamichatani, W., Kajiwara, T., Yanai, H., Saito, M., and 188 Tohda, K.: A solid phase extraction using a chelate resin immobilizing carboxymethylated 189 pentaethylenehexamine for separation and preconcentration of trace elements in water 190 samples, Talanta, 79, 146-152, 2009.

191 Ma, S., Tao, Z., Yang, X., Yu, Y., Zhou, X., M, W., and Li, Z.: Estimation of marine primary 192 productivity from satellite-derived phytoplankton absorption data, IEEE J-STARS, 7, 3084193 3092, 2014. 
194 McManus, J., Berelson, W. M., Severmann, S., Johnson, K. S., Hammond, D. E., Roy, M., 195 and Coale, K. H.: Benthic manganese fluxes along the Oregon-California continental shelf 196 and slope, Cont. Shelf Res., 43, 71-85, 2012.

197 Millero, F. J., Sotolongo, S., and Izaguirre, M.: The oxidation kinetics of Fe(II) in seawater, 198 Geochim. Cosmochim. Act., 51, 793-801, 1987.

199 Raiswell, R. and Anderson, T. F.: Reactive iron enrichment in sediments deposited beneath 200 euxinic bottom waters: constraints on supply by shelf recycling, Geological Society, London, 201 Special Publications, 2005.

202 Rapp, I., Schlosser, C., Rusiecka, D., Gledhill, M., and Achterberg, E. P.: Automated 203 preconcentration of $\mathrm{Fe}, \mathrm{Zn}, \mathrm{Cu}, \mathrm{Ni}, \mathrm{Cd}, \mathrm{Pb}, \mathrm{Co}$, and $\mathrm{Mn}$ in seawater with analysis using high204 resolution sector field inductively-coupled plasma mass spectrometry, Anal. Chimi. Acta, $205976,1-13,2017$.

206 Strzepek, R., Maldonado, M. T., Hunter, K. A., Frew, R. D., and Boyd, P. W.: Adaptive 207 strategies by Southern Ocean phytoplankton to lessen iron limitation: Uptake of organically 208 complexed iron and reduced cellular iron requirements, Limnol. Oceanogr., 56, 1983-2002, 2092011.

210 Twining, B. S., Baines, S. B., Fisher, N. S., and Landry, M. R.: Cellular iron contents of 211 plankton during the Southern Ocean Iron Experiment (SOFeX), Deep-Sea Res. I, 51, 1827$2121850,2004$.

213 